\title{
PELVIC AND FEMORAL ANATOMY OF THE ALLODAPOSUCHIDAE (CROCODYLIFORMES, EUSUCHIA) FROM THE LATE CRETACEOUS OF LO HUECO (CUENCA, SPAIN)
}

\author{
A. de Celis ${ }^{1 *}$, I. Narváez $^{1}$, F. Ortega ${ }^{1}$ \\ ${ }^{1}$ Grupo de Biología Evolutiva, Facultad de Ciencias, UNED, Paseo de la Senda del Rey 9, \\ 28040 Madrid, Spain. \\ e-mail addresses: ane.detecla@gmail.com (A.d.C., *Corresponding author); \\ i.narvaez.padilla@gmail.com (I.N.),fortega@ccia.uned.es (F.O.).
}

\begin{abstract}
Purpose The fossil record of postcranial remains assigned to Allodaposuchidae is currently sparse. However, the Late Cretaceous paleontological site of Lo Hueco (Cuenca, Spain), from where two new taxa of allodaposuchid have been described, has yielded numerous postcranial remains assignable to this clade. Among them, the large amount of pelvic and femoral material is notable, providing the opportunity to study these allodaposuchid elements and assess their morphological similarity with other eusuchian remains.
\end{abstract}

Methods The comparison with extant crocodylians was accomplished using traditional morphometric techniques, whereas the comparison with other fossils and establishment of morphotypes was done using morphological criteria.

Results The results of the cluster and principal components analyses show morphological differences between extant crocodylians and allodaposuchids from Lo Hueco, allowing the segregation of these lineages. The similarities found between the pelvic and femoral remains from Lo Hueco, and those referred to Allodaposuchus precedens and other putative allodaposuchids from the Iberian Peninsula, allows referral of these remains to allodaposuchids. The differences found among the femoral and pelvic remains of Lo Hueco enables us to recognize two morphotypes per each element. 
Conclusions This study allows a better understanding of allodaposuchid postcranial elements that were previously poorly known. The ilia, ischia and femora from Lo Hueco allodaposuchids are distinct from those of other crocodylian lineages. Finally, the fact that there are two morphotypes per each element at Lo Hueco is congruent with the presence of two different allodaposuchids at the site.

Key words: Allodaposuchidae, Iberian Peninsula, postcranial, morphometrics, PCA.

\section{RESUMEN}

Propósito El registro fósil contiene escasos restos postcraneales asignados a Allodaposuchidae. Sin embargo, en el yacimiento paleontológico del Cretácico Superior de Lo Hueco (Cuenca, España), del cual se han descrito dos nuevas especies de alodaposúquido, se han recuperado numerosos restos fósiles postcraneales asignables a este clado. Entre ellos destaca la cantidad de restos pélvicos y fémorales recuperados. Esto ofrece la oportunidad de estudiarlos y evaluar su semejanza morfológica con restos de otros eusuquios.

Métodos La comparación con cocodrilos actuales se realizó empleando técnicas morfométricas tradicionales, mientras que la comparación con otros restos fósiles y el establecimiento de morfotipos se efectuó utilizando criterios morfológicos.

Resultados Los resultados de los análisis de clúster y de componentes principales muestran que existen diferencias morfológicas entre los restos de cocodrilos actuales y los restos de los alodaposúquidos de Lo Hueco, permitiendo la segregación de estos linajes. La similitud encontrada entre los restos pélvicos y femorales de Lo Hueco, y aquellos asignados a Allodaposuchus precedens y otros supuestos alodaposúquidos de la península ibérica, permite asignar estos restos a alodaposúquidos. Las diferencias encontradas entre el material femoral y pélvico de Lo Hueco permite reconocer dos morfotipos para cada elemento postcraneal estudiado. 
Conclusiones El presente estudio posibilita un mejor entendimiento de estos restos postcraneales en alodaposúquidos, previamente poco conocidos. Los iliones, isquiones y fémures de los alodaposúquidos de Lo Hueco son distintos de los de miembros de los linajes de Crocodylia. Por último, el hecho de que existan dos morfotipos de cada elemento estudiado de Lo Hueco es congruente con la presencia de dos especies distintas de alodaposúquido en el yacimiento.

Palabras clave: Allodaposuchidae, Península ibérica, postcraneal, morfometría, PCA.

The complete read-only version of the peer-reviewed article is available here $\underline{\text { http://rdcu.be/BCVv }}$ 